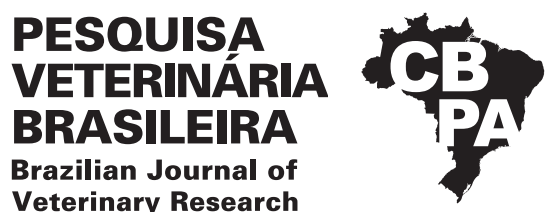

Pesq. Vet. Bras. 41:e06872, 2021

DOI: $10.1590 / 1678-5150-P V B-6872$

Original Article

arv Research

Livestock Diseases

ISSN 0100-736X (Print)

(cc) BY-NC

ISSN 1678-5150 (Online)

\title{
Diseases of the central nervous system in swine in Southern Brazil ${ }^{1}$
}

\author{
Márcia E. Hammerschmitt ${ }^{2 *}(\mathbb{D})$, Bruno A. Almeida² ${ }^{D}$, Paula R. Pereira² ${ }^{\mathbb{D}}$, Saulo P. \\ Pavarini $^{2}$ (D) Luciana Sonne ${ }^{2}$ (D) and David Driemeier ${ }^{2}$ (D)
}

\begin{abstract}
Hammerschmitt M.E., Almeida B.A., Pereira P.R., Pavarini S.P., Sonne L. \& Driemeier D. 2021. Diseases of the central nervous system in swine in Southern Brazil. Pesquisa Veterinária Brasileira 41:e06872, 2021. Setor de Patologia Veterinária, Departamento de Patologia Clínica Veterinária, Faculdade de Veterinária, Universidade Federal do Rio Grande do Sul, Av. Bento Gonçalves 9090, Prédio 42505, Porto Alegre, RS 91540-000, Brazil. E-mail: marciahammer@hotmail.com

Brazil is the fourth largest exporter of pork worldwide, with its production concentrated in the Southern region of the country. To reduce the economic impacts and increase herd health, an efficient diagnosis of diseases is necessary. The frequency, seasonal, and annual distribution of diseases that affecting the swine nervous system in Southern Brazil were determined through a retrospective study conducted from 2008 to 2018. A total of 231 pigs were evaluated, and distributed in the following phases: suckling piglets, nursery, growing, finishing, and adults. Piglets in the nursery phase were the most affected with $58.01 \%$. Infectious diseases accounted for $87.01 \%$ (201/231) of lesions in the nervous system. Bacterial meningitis was observed in $58.87 \%$ of cases, presenting an endemic distribution, and a propensity to occur in the months of autumn/winter. The highest number of cases of porcine circovirus- 2 were observed in 2008 and 2009, with a subsequent decline. Porcine circovirus, salt poisoning, and brain abscesses exhibited no association between the seasonal occurrence and annual distribution. Salt poisoning was observed more frequently in the last years of this study. Both, non-suppurative encephalomyelitis and selenium toxicosis exhibited an association between their occurrence and seasonal distribution in, the months of winter, and summer, respectively.
\end{abstract}

INDEX TERMS: Swine diseases, nervous system, meningitis, salt poisoning, pigs, Brazil.

RESUMO.- [Doenças do sistema nervoso central de suínos no Sul do Brasil.] Brasil é o quarto maior exportador de carne suína do mundo, com sua produção concentrada na região Sul do país. Para reduzir os impactos econômicos e aumentar a saúde do rebanho, é necessário o diagnóstico eficiente das doenças. A frequência, distribuição sazonal e anual das doenças que afetam o sistema nervoso de suínos no Sul do Brasil foram determinadas através de um estudo retrospectivo no período de 2008 a 2018. Foram avaliados 231 suínos, distribuídos nas seguintes fases: maternidade, creche, crescimento, terminação e adultos. Leitões da fase de creche foram os mais afetados com 58,01\%. As doenças de origem infecciosa foram responsáveis por 87,01\% (201/231) das

\footnotetext{
${ }^{1}$ Received on May 28, 2021.

Accepted for publication on July 7, 2021

${ }^{2}$ Setor de Patologia Veterinária (SPV), Departamento de Patologia Clínica Veterinária, Faculdade de Veterinária (Favet), Universidade Federal do Rio Grande do Sul (UFRGS), Av. Bento Gonçalves 9090, Prédio 42505, Porto Alegre, RS 91540-000, Brazil. *Corresponding author: marciahammer@hotmail.com
}

causas de lesões no sistema nervoso. Meningite bacteriana foi observada em 58,87\% dos casos, apresentando distribuição endêmica, e uma tendência a ocorrer nos meses de outono/ inverno. O maior número de casos de circovírus suíno foram observados em 2008 e 2009, com declínio posterior. Circovírus suíno, intoxicação por sal e os abscessos encefálicos não apresentaram associação entre a ocorrência sazonal e distribuição anual. A intoxicação por sal foi observada com maior frequência nos últimos anos deste estudo. A encefalomielite não supurativa e a intoxicação por selênio exibiram associação entre a sua ocorrência e distribuição sazonal, nos meses de inverno e verão, respectivamente.

TERMOS DE INDEXAÇÃO: Doenças dos suínos, sistema nervoso, meningite, intoxicação por sal, suínos, Brasil.

\section{INTRODUCTION}

Brazil is the fourth largest producer and exporter of pork worldwide. The Southern region of the country is the largest 
pork exporter (Guedes et al. 2017, ABPA 2020). Nervous system diseases frequently occur in swine and are responsible for high economic losses (Rademacher 2001, Jackson \& Cockcroft 2007, Gottschalk \& Segura 2019, Madson et al. 2019). Diseases that affect the central nervous system of pigs can be infectious, non-infectious, or exhibit a multifactorial origin (Madson et al. 2019). Infectious diseases are the main cause of death in pigs and can impact the production costs severely (Maes et al. 2001, Sobestiansky et al. 2012a, Brum et al. 2013a, Konradt et al. 2020, Piva et al. 2020). Therefore, the recognition and effective diagnosis of such diseases must be prioritized (Ciacci-Zanella et al. 2016, Guedes et al. 2017, Gottschalk \& Segura 2019). Although the epidemiological studies are scarce, endemic diseases occur in most technified farms (Ciacci-Zanella et al. 2016). In this study, we aimed to determine the frequency of diseases that affect the central nervous system (CNS) of swine in Southern Brazil, and investigate their seasonal and annual distribution through a retrospective study conducted from 2008 to 2018.

\section{MATERIALS AND METHODS}

The reports of histopathological examinations and necropsies of pigs in the veterinary pathology laboratory were reviewed from January 2008 to December 2018. The selected cases exhibited microscopic lesions in the CNS. The information regarding age, seasonal occurrence, and annual distribution was extracted using these protocols. The swines belonged to the intensive production farms in the states of Rio Grande do Sul, Santa Catarina, and Paraná. They were categorized into the following phases: suckling piglets (1-21 days), nursery (22-61 days), growing (62-120 days), finishing (121-160 days), and adults (over 161 days) (Machado 2014). Based on the histological lesions, the diagnoses were grouped into the following categories: bacterial meningitis, brain abscesses, porcine circovirus, non-suppurative encephalomyelitis, salt poisoning, and selenium poisoning. The samples used in this study were obtained from pigs affected with natural diseases. Disease frequencies were analyzed using the descriptive statistics, Pearson's chi-square test ( 2 ), or exact test (ET) (Mehta \& Patel 2011). The ET was used for diseases that did not meet the criteria for using $\chi 2$ : in tables larger than $2 \times 2$, a minimum expected count of 1 is permissible when no more than $20 \%$ of the cells have an expected count less than 5 (Cochran 1954). Therefore, salt poisoning, selenium poisoning, and brain abscesses were assessed using ET. IBM Statistical Package for the Social Sciences (SPSS version 22 IBM Corp) was used to assess the statistical significance, and $p$-value $<0.05$ was considered significant.

\section{RESULTS}

A total of 7,230 cases were reviewed, and 231 (3.19\%) samples exhibited lesions in the nervous system. Samples from the state of Rio Grande Sul accounted for 58.01\% (134/231) of cases, followed by Paraná 29\% (67/231), and Santa Catarina $12.99 \%(30 / 231)$. As per the age group, $6.49 \%(15 / 231)$ of the samples were from the suckling piglets, $58.01 \%(134 / 231)$ were from the nursery, $24.24 \%$ (56/231) were from the growing, $6.06 \%$ (14/231) were from the finishing, and $1.3 \%$ $(3 / 231)$ were from the adult pigs, and 3.9\% (9/231) had no age information. Piglets in the nursery phase were found to be the most affected group (58.01\%), and the piglets diagnosed with bacterial meningitis, non-suppurative encephalomyelitis, porcine circovirus, salt poisoning, and selenium poisoning, were with a median age of $50,55,49,50$, and 30 days, respectively.

Infectious diseases (bacterial meningitis, brain abscesses, porcine circovirus, and non-suppurative encephalomyelitis) were responsible for $87.01 \%$ (201/231) of lesions in the CNS, while intoxication (salt and selenium) had 12.99\% (30/231). The seasonal occurrence of these diseases and intoxications is depicted in Figure 1, whereas the annual distribution is present in Table 1.

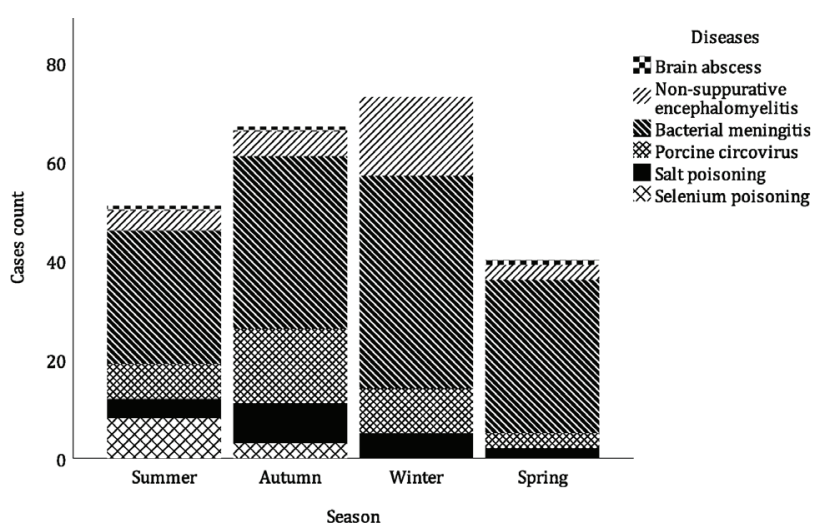

Fig.1. Seasonality of the diseases affecting the central nervous system in pigs in Southern Brazil.

Table 1. Distribution of diseases affecting the central nervous system of swine according to the year in southern Brazil

\begin{tabular}{|c|c|c|c|c|c|c|}
\hline Year & Brain abscess & Encephalomyelitis & Bacterial meningitis & Porcine circovirus & Salt poisoning & Selenium poisoning \\
\hline 2008 & 0 & 0 & 10 & 8 & 3 & 0 \\
\hline 2009 & 0 & 0 & 19 & 7 & 2 & 0 \\
\hline 2010 & 0 & 0 & 9 & 2 & 0 & 0 \\
\hline 2011 & 0 & 8 & 20 & 5 & 1 & 3 \\
\hline 2012 & 0 & 0 & 18 & 4 & 2 & 8 \\
\hline 2013 & 0 & 0 & 14 & 0 & 0 & 0 \\
\hline 2014 & 1 & 0 & 9 & 0 & 0 & 0 \\
\hline 2015 & 0 & 2 & 15 & 4 & 7 & 0 \\
\hline 2016 & 1 & 0 & 9 & 0 & 2 & 0 \\
\hline 2017 & 1 & 16 & 7 & 2 & 0 & 0 \\
\hline 2018 & 0 & 2 & 6 & 2 & 2 & 0 \\
\hline TOTAL & 3 & 28 & 136 & 34 & 19 & 11 \\
\hline
\end{tabular}


Bacterial meningitis was the most frequent lesion, which was observed in 58.87\% (136/231) of the cases. Although there was no seasonal association $(p=0.052)$, a trend of higher occurrence was observed in the months of autumn and winter (57.35\%, 78/136). Bacterial meningitis was along the year and over 10 years. Porcine circovirus (PCV) (14.72\%, 34/231), salt poisoning $(8.23 \%, 19 / 231)$ and brain abscesses $(1.3 \%$, $3 / 231$ ) did not show an association between the season and number of diagnoses performed $(p=0.155, p=0.647$ and $p=0.541$, respectively). Cases of PCV were observed more frequently in 2008 and 2009, and then declined gradually. Salt poisoning was been observed more frequently in the last four years of this study.

Non-suppurative encephalomyelitis and selenium poisoning showed an association between disease occurrence and season. Non-suppurative encephalomyelitis was observed in $12.12 \%$ of cases $(28 / 231)$, with a higher occurrence in winter $(57.14 \%, 16 / 28, p=0.021)$. In ten $(10 / 28)$ samples the lesion was associated with Teschovirus $A$ (Hammerschmitt et al. 2021). Selenium poisoning was observed in $4.76 \%$ of the cases $(11 / 231)$ with greater occurrence in the summer (72.73\%, 8/11, $p<0.001)$.

\section{DISCUSSION}

In this retrospective study, CNS diseases accounted for $3.19 \%$ of the diagnoses in pigs. These data are similar to those of a study conducted in the south of Rio Grande do Sul with swines of subsistence activity (Coelho et al. 2017). The diseases of the CNS in pigs are common in farms and exert high economic losses. Some pathogens, such as Streptococcus sp., which reside in the palatine tonsils of healthy pigs, are part of the pig's microbiota, and can cause epidemics in the presence of stress factors (Staats et al. 1997, Rademacher 2001, Gottschalk \& Segura 2019, Madson et al. 2019), thereby increasing the rate of mortality.

Nursery pigs were the most affected group in this study, accounting for $58.01 \%$ of the cases. In the nursery phase, cases of all diseases were observed, as well as the largest number of cases, except for abscess. This phase is characterized by numerous stressful factors, such as a decrease in passive immunity and tension that affect the animal behavior. Additionally, mixing pigs from different farms, which allows their contact with different variants and/or microorganisms, leads to a consequent increase in the infection pressure (Morés \& Amaral 2001, Sobestiansky et al. 2012a).

Infectious diseases were the most frequent in this study, as also observed in other studies. The frequency of infectious diseases is high, because the diagnosis in the field is hampered by the absence of macroscopic lesions, and thus, the samples are submitted to perform laboratory tests, such as histopathology (Morés 2009, Konradt et al. 2020, Piva et al. 2020). A variety of pathogens are present in swine farms, which can lead to disease, and, consequently, reduced performance and increases in the production costs (Fablet 2009, Brum et al. 2013a). The agents are controlled by the swine immune system, in addition to predisposing factors and the use of antibiotics (Fablet 2009, Ciacci-Zanella et al. 2016).

Bacterial meningitis was the most frequent diagnosed disease in this study. Meningitis occurs frequently in pigs between five to 10 weeks (Madson et al. 2019), and exhibits a low frequency in those between growing-finishing phase (Piva et al. 2020). It is possible that, the high frequency observed in this study was because we included pigs of all ages (suckling to adults age). Streptococcus suis is a pathogen that is frequently isolated from meningitis. S. suis is one of the most important swine pathogens worldwide (Gottschalk \& Segura 2019), and is endemic to most swine farms (Pagnani et al. 2002). The samples of this study were from commercial farms, and the endemic distribution over the years corroborates with the previous data. Although there was no seasonal variation, the months of autumn and winter exhibited a greater tendency for the disease to occur. This may be related, among other causes, to the temperature fluctuations and improper ventilation (Santos \& Barcellos 2012).

Porcine circovirus- 2 was the second most common disease diagnosed in this study, and is an important cause of death in pigs in Brazil (Brum et al. 2013a, Piva et al. 2020). Porcine circovirus is the causative agent of a number of diseases and syndromes in pigs, but only a few reports have described the neurological lesions (Corrêa et al. 2007, Seeliger et al. 2007, Zlotowski et al. 2013, Segalés et al. 2019). Circoviruses are predominantly observed in pigs between five to 12 weeks of age (CiacciZanella et al. 2015). Meningoencephalitis, leptomeningitis, and lymphohistiocytic and necrotizing vasculitis in the cerebellum were described in this age group (Rosell et al. 1999, Clark et al. 2004, Corrêa et al. 2007, Seeliger et al. 2007), while spinal cord lesions were observed in finishing pigs (Zlotowski et al. 2013). The median age observed in this study was 49 days, which is similar to that described by Seeliger et al. (2007). After the introduction of commercial vaccines, there was a significant reduction in the number of pigs affected in Brazilian farms (Guedes 2012, Ciacci-Zanella et al. 2015, Ciacci-Zanella 2017), which may explain the high frequency observed in 2008 and 2009, and the subsequent decline observed in this study.

Non-suppurative encephalomyelitis can be observed in cases of rabies, pseudorabies (Mettenleiter et al. 2019, Swenson et al. 2019), and most recently have been linked to Mammastrovirus 3 (porcine astrovirus) (Arruda et al. 2017a), Sapelovirus A (porcine sapelovirus - PSV) (Arruda et al. 2017b), and Teschovirus A (porcine teschovirus - PTV) (Vreman et al. 2020). Recently, cases of non-suppurative encephalomyelitis associated with PTV have been described in Brazilian commercial farms (Hammerschmitt et al. 2021), in addition to the molecular detection of PSV in wild boar and domestic swine without clinical signs (Donin et al. $2014,2015)$. The involvement of these viral agents in the other cases observed in this study is not ruled out. Rabies is uncommon diseases in pigs and pseudorabies has not been reported since 2004 in Southern Brazil (Roehe \& Brito 2012, Ciacci-Zanella et al. 2016). Most cases of non-suppurative encephalomyelitis occurred in the months of winter, which may be related to the favorable temperature, humidity, and solar radiation, which is crucial for the survival of viruses in the environment (Flores \& Traesel 2012).

Brain abscesses represented $1.3 \%$ of the lesions in this study. Abscesses in the CNS seem to be an uncommon disease, and not reported in other similar studies (Brum et al. 2013a, Coelho et al. 2017, Konradt et al. 2020). However, this disease has been reported in the isolated cases (Headley et al. 2012). We believe that the occurrence of isolated cases within the farms and the evident macroscopic findings contribute to the fact that only a few brain abscesses samples are sent to the laboratory. 
Toxic diseases are often associated with management errors in the production units (Brum et al. 2013b, Gomes et al. 2014). Salt poisoning is a common condition in pigs production and is related to numerous factors, including the interruption of water supply (Sobestiansky et al. 2012b, Miller \& Zachary 2017), and thus, poisoning occurs in the form of outbreaks (Boos et al. 2012, Brum et al. 2013b). The supply of alternative diets, such as waste or by-products of dairy factories, has gained attention within the swine industry, which is attributed to its nutritional value (Martins et al. 2008). Salt poisoning exhibited a higher frequency in this study than that described by other authors (Brum et al. 2013b), and exhibited an increase in the last four years of this study, which may be linked to the provision of alternative diets to the different stages of swine nutrition (Martins et al. 2008). This disease appears to be closely linked to the management factors on farms, which may explain the absence of seasonal variation.

Selenium poisoning was observed in $4.76 \%$ of cases. Other retrospective studies in pigs did not list this diagnosis (Brum et al. 2013b, Coelho et al. 2017). Selenium is an essential microelement, and thus, added to the feed formulations (Sobestiansky et al. 2012b). Errors in the formulations or homogenization of feed result in excessive intake and intoxication (Casteignau et al. 2006, Nathues et al. 2010, Sobestiansky et al. 2012b, Gomes et al. 2014). The seasonal variation and the epidemic distribution are possibly explained by the fact that these cases were only observed on two occasions.

\section{CONCLUSIONS}

Infectious diseases were accounted for $87.01 \%$ of the lesions in the swine nervous system in Southern Brazil.

Nursery piglets were the most affected group.

Bacterial meningitis is the most common disease among infectious disease, and is endemic to swine farms in Southern Brazil.

Porcine circovirus was a frequently disease observed, with high frequency in 2008 and 2009.

Toxic diseases occur in outbreaks, and salt poisoning have the highest number of cases, which did not exhibit seasonal variation.

Authors' contributions.- Hammerschmitt M.E., Almeida B.A., Pereira P.R., Pavarini S.P., Sonne L. \& Driemeier D. made substantial contributions to the interpretation of data. Approved the version to be published.

Acknowledgments.- The authors thank the "Conselho Nacional de Desenvolvimento Científico e Tecnológico" (CNPq) and "Coordenação de Aperfeiçoamento de Pessoal de Nível Superior" (CAPES) for supporting this study.

Conflict of interest statement.- The authors declared no potential conflicts of interest with respect to the research, authorship, and/or publication of this article.

\section{REFERENCES}

ABPA 2020. Relatório anual 2020. Associação Brasileira de Proteína Animal. Available at: <https://abpa-br.org/wp-content/uploads/2020/05/ abpa_relatorio_anual_2020_portugues_web.pdf > Accessed on Dec. 9, 2020.

Arruda B., Arruda P., Hensch M., Chen Q., Zheng Y., Yang C., Gatto I.R.H., Ferreyra F.M., Gauger P., Schwartz K. Bradner L., Harmon K. Hause B. \& Li G. 2017a. Porcine astrovirus type 3 in central nervous system of swine with polioencephalomyelitis. Emerg. Infect. Dis. 23(12):2097-2100. <https:// dx.doi.org/10.3201/eid2312.170703> <PMid:29148383>

Arruda P.H.E., Arruda B.L., Schwartz K.J., Vannucci F., Resende T., Rovira A., Sundberg P., Nietfeld J. \& Hause B.M. 2017b. Detection of a novel sapelovirus in central nervous tissue of pigs with polioencephalomyelitis in the USA. Transbound. Emerg. Dis. 64(2):311-315. <<https://dx.doi.org/10.1111/ tbed.12621> <PMid:28160432>

Boos G.S., Watanabe T.T.N., Almeida P.R., Oliveira L.G.S., Pavarini S.P., Zlotowski P. \& Driemeier D. 2012. Surto de intoxicação por sal em suínos em Santa Catarina. Pesq. Vet. Bras. 32(4):329-332. <https://dx.doi.org/10.1590/ S0100-736X2012000400009>

Brum J.S., Galiza G.J.N., Lucena R.B. \& Barros C.S.L. 2013b. Intoxicação por sal em suínos: aspectos epidemiológicos, clínicos e patológicos e breve revisão de literatura. Pesq. Vet. Bras. 33(7):890-900. <https://dx.doi. org/10.1590/S0100-736X2013000700009>

Brum J.S., Konradt G., Bazzi T., Fighera R.A., Kommers G.D., Irigoyen L.F. \& Barros C.S.L. 2013a. Características e frequência das doenças de suínos na Região Central do Rio Grande do Sul. Pesq. Vet. Bras. 33(10):1208-1213. <https://dx.doi.org/10.1590/S0100-736X2013001000006>

Casteignau A., Fontan A., Morillo A., Oliveros J.A. \& Segales J. 2006. Clinical, pathological and toxicological findings of a iatrogenic selenium toxicosis case in feeder pigs. J. Vet. Med. A, Physiol. Pathol. Clin. Med. 53(6):323-326. <https://dx.doi.org/10.1111/j.1439-0442.2006.00830.x><PMid:16901278>

Ciacci-Zanella J.R. 2017. Situação atual da circovirose no Brasil. Anais XVIII Congresso da Abraves, Goiânia, GO, p.150-156.

Ciacci-Zanella J.R., Morés N. \& Barcellos D.E.S.N. 2016. Principais ameaças sanitárias endêmicas da cadeia produtiva de suínos no Brasil. Pesq. Agropec. Bras. 51(5):443-453. <https://dx.doi.org/10.1590/S0100204X2016000500004>

Ciacci-Zanella J.R., Schaefer R., Gava D., Mores N. \& Barcellos D. 2015. Novos conhecimentos sobre a infecção por PCV2 e a emergência de novas estirpes virais. Avanços em Sanidade, Produção e Reprodução de Suínos, Anais do IX Simpósio Internacional de Suinocultura (SINSUI), Porto Alegre, RS, p.207-220.

Clark E.G., Ellis J.A., Allan G.M. \& Krakowka S. 2004. Postweaning multisystemic wasting syndrome in swine. In: Infectious diseases of livestock, p.1374-1386. In: Coetzer J.A.W. \& Tustin R.C. (Eds), Infectious Diseases of Livestock. 2nd ed. Oxford University Press, Oxford.

Cochran W.G. 1954 Some methods for strengthening the common $\chi 2$ Tests. Biometrics 10(4):417-451. <https://dx.doi.org/10.2307/3001616>

Coelho A.C.B., Oliveira P.A., Santos B.L., Zamboni R., Silva P.E., Pereira C.M., Soares M.P., Sallis E.S. \& Schild A.L. 2017. Doenças de suínos diagnosticadas em criações de subsistência na região Sul do Brasil. Revta Invest. Vet. 16(8):56-61. <https://dx.doi.org/10.26843/investigacao.v16i8.1901>

Corrêa A.M.R., Zlotowski P., Barcellos D.E.S.N., Cruz C.E.F. \& Driemeier D. 2007. Brain lesions in pigs affected with postweaning multisystemic wasting syndrome. J. Vet. Diagn. Invest. 19(1):109-112. <https://dx.doi. org/10.1177/104063870701900120><PMid:17459844>

Donin D.G., Leme R.A., Alfieri A.F., Alberton G.C. \& Alfieri A.A. 2014. First report of porcine teschovirus (PTV), porcine sapelovirus (PSV) and enterovirus G (EV-G) in pig herds of Brazil. Trop. Anim. Health Prod. 46(3):523-528. <https://dx.doi.org/10.1007/s11250-013-0523-z><PMid:24362793>

Donin D.G., Leme R.A., Alfieri A.F., Alberton G.C. \& Alfieri A.A. 2015. Molecular survey of porcine teschovirus, porcine sapelovirus, and enterovirus $G$ in captive wild boars (Sus scrofa scrofa) of Paraná state, Brazil. Pesq. Vet. Bras. 35(5):403-408. <https://dx.doi.org/10.1590/S0100-736X2015000500003>

Fablet C. 2009. An overview of the impact of the environment on enzootic respiratory diseases in pigs, p.239-260. In: Aland A. \& Madec F. (Eds), Sustainable Animal Production: the challenges and potential developments for professional farming. Wageningen Academic Publishers, Wageningen. 
Flores E.F. \& Traesel C.K. 2012. Epidemiologia das infecções víricas, p.280324. In: Flores E.F. (Ed.), Virologia Veterinária: virologia geral e doenças víricas. $2^{\mathrm{a}}$ ed. Editora UFSM, Santa Maria.

Gomes D.C., Souza S.O., Juffo G.D., Pavarini S.P. \& Driemeier D. 2014. Intoxicação por selênio em suínos no Sul do Brasil. Pesq. Vet. Bras. 34(12):1203-1209. <https://dx.doi.org/10.1590/S0100-736X2014001200010>

Gottschalk M. \& Segura M. 2019. Streptococcosis, p.934-950. In: Zimmermann J.J., Karriker L.A., Ramirez A., Schwartz K.J., Stevenson G.W. \& Zhang J. (Eds), Diseases of Swine. 11th ed. Wiley-Blackwell, Hoboken.

Guedes R.M.C. 2012. Como monitorar infecções subclínicas causando perdas de desempenho na recria e terminação. Soc. Med. Vet. Uruguay 48(Supl.1):49-51.

Guedes R.M.C., Gabardo M.P., Santos R.L., Sarakides R. \& Ecco R. 2017. Prefácio suínos, p.6. In: Martins N.R.S., Santos R.L., Coelho S.G., Marques Junior A.P. \& Rocha B.D. (Eds), Cadernos Técnicos de Veterinária e Zootecnia FEPMVZ, № 86, Minas Gerais, MG.

Hammerschmitt M.E., Almeida P.R., Cecco B.S., Lorenzett M.P., Schwertz C.I., Cruz R.A.S., Caprioli R.A., Schuh D.T., Demoliner M., Eisen A.K.A., Spilki F.R., Pavarini S.P. \& Driemeier D. 2021. Swine polioencephalomyelitis in Brazil: identification os Teschovirus A, Sapelovirus A, and Enterovirus $G$ in a farm from Southern Brazil. Braz. J. Microbiol. 52(3):1617-1622. <https://dx.doi. org/10.1007/s42770-021-00509-z> <PMid:34024036>

Headley S.A., Silva L.C. \& Okano W. 2012. Cerebral abscesses in a pig: atypical manifestations of Streptococcus suis serotype 2-induced meningoencephalitis. J. Swine Health Prod. 20(4):179-183.

Jackson P.G.G. \& Cockcroft P.D. 2007. Diseases of the nervous system, p.128141. In: Ibid. (Eds), Handbook of Pig Medicine. Saunders Elsevier, London.

Konradt G., Bassuino D.M., Siqueira L.C., Bianchi M.V., Sonne L., Driemeier D. \& Pavarini S.P. 2020. Infectious diseases dynamics in growing/finishin pigs in Southern Brazil (2005-2016). Pesq. Vet. Bras. 40(4):254-260. <https:// dx.doi.org/10.1590/1678-5150-pvb-6510>

Machado I.P. 2014. Fluxo de produção e dimensionamento de instalações, p.106-110. In: Associação Brasileira de Criadores de Suínos (Eds), Produção de Suínos Teoria e Prática. Integrall, Brasília.

Madson D.M., Arruda P.H.E. \& Arruda B.L. 2019. Nervous and locomotor system, p.339-371. In: Zimmerman J.J., Karriker L.A., Ramirez A., Schwartz K.J., Stevenson G.W. \& Zhang J. (Eds), Diseases of Swine. 11th ed. WileyBlackwell, Hoboken.

Maes D., Larriestra A., Deen J. \& Morrison R.B. 2001. A retrospective study of mortality in grow-finish pigs in a multi-site production system. J. Swine Health Prod. 9(6):267-273.

Martins T.D.D., Pimenta Filho E.C., Costa R.G. \& Souza J.H.M. 2008. Soro de queijo líquido na alimentação de suínos em crescimento. Revta Ciênc. Agron. 39(2):301-307.

Mehta C.R. \& Patel N.R. 2011. IBM SPSS exact tests. IBM Corporation, Armonk, NY.

Mettenleiter T.C., Ehlers B., Müller T., Yoon K.J. \& Teifke J.P. 2019. Herpesviruses, p.548-575. In: Zimmermann J.J., Karriker L.A., Ramirez A., Schwartz K.J., Stevenson G.W. \& Zhang J. (Eds), Diseases of Swine. 11th ed. WileyBlackwell, Hoboken.

Miller A.D. \& Zachary J.F. 2017. Nervous system, p.805-907. In: Zachary J.F. (Ed.), Pathologic Basis of Veterinary Disease. 6th ed. Mosby Elsevier, St Louis.

Morés N. \& Amaral A.L. 2001. Patologias associadas ao desmame, p.215-224. Anais do X Congresso da Associação Brasileira de Veterinários Especialistas em Suínos, Porto Alegre, Brasil.
Morés N. 2009. Torção do mesentério ou síndrome hemorrágica intestinal: qual a importância, como reconhecer, quais as causas e como controlar as perdas causadas. Acta Scient. Vet. 37(Supl.1):s11-s15.

Nathues H., Boehne I., Beilage T.G., Gerhauser I., Hewicker-Trautwein M., Wolf P., Kamphues J. \& Beilage E.G. 2010. Peracute selenium toxicosis followed by sudden death in growing and finishing pigs. Can. Vet. J. 51:515-518. <PMid:20676295>

Pagnani K.J.R., Castro A.F.P., Gottschalk M., Silveira W.D. \& Nakazato G. 2002. Sorotipagem de amostras de Streptococcus suis isoladas de suínos em granjas dos Estados de São Paulo, Minas Gerais e Paraná. Pesq. Vet. Bras. 22(1):1-5. <https://dx.doi.org/10.1590/S0100-736X2002000100002>

Piva M.M., Schwertz C.I., Bianchi R.M., Kemper R.T., Henker L.C., Nagae R.Y., Cê T.R.M., Barcellos D.E.S.N., Driemeier D. \& Pavarini S.P. 2020. Causes of death in growing finishing pigs in two technified farms in southern Brazil. Pesq. Vet. Bras. 40(10):758-775. <https://dx.doi.org/10.1590/1678-5150-PVB-6708>

Rademacher C.J. 2001. Diagnostic approaches to swine central nervous system disorders - a practitioner's perspective. J. Swine Health Prod. 9(1):31-33.

Roehe P. \& Brito W. 2012. Raiva, p.390-393. In: Sobestiansky J. \& Barcellos D. (Eds), Doenças dos Suínos. $2^{\text {a }}$ ed. Canône Editorial, Goiânia.

Rosell C., Segalés J., Plana-Durán J., Balasch M., Rodríguez-Arrioja G.M., Kennedy S., Allan G.M., McNeilly F., Latimer K.S. \& Domingo M. 1999 Pathological, immunohistochemical, and in-situ hybridization studies of natural cases of postweaning multisystemic wasting syndrome (PMWS) in pigs. J. Comp. Pathol. 120(1):59-78. <https://dx.doi.org/10.1053/ jcpa.1998.0258><PMid:10098016>

Santos J.L. \& Barcellos D. 2012. Meningite estreptocócica, p.203-209. In: Sobestiansky J. \& Barcellos D. (Eds), Doenças dos Suínos. 2ª ed. Canône Editorial, Goiânia.

Seeliger F.A., Brügmann M.L., Kruger L., Greiser-Wilke I., Verspohl J., Segalés J. \& Baumgärtner W. 2007. Porcine circovirus type 2-associated cerebellar vasculitis in postweaning multisystemic wasting syndrome (PMWS) affected pigs. Vet. Pathol. 44(5):621-634. <https://dx.doi.org/10.1354/ vp.44-5-621><PMid:17846234>

Segalés J., Allan G.M. \& Domingo M. 2019. Circoviruses, p.473-487. In: Zimmerman J.J., Karriker L.A., Ramirez A., Schwartz K.J., Stevenson G.W \& Zhang J. (Eds), Diseases of Swine. 11th ed. Wiley-Blackwell, Hoboken.

Sobestiansky J., Morés N., Souza M.A. \& Moreno A.M. 2012b. Intoxicações por minerais, produtos químicos, plantas e gases, p.551-580. In: Sobestiansky J. \& Barcellos D. (Eds), Doenças dos Suínos. $2^{\text {a }}$ ed. Canône Editorial, Goiânia.

Sobestiansky J., Morés N., Weiblen R., Reis R. \& Barcellos D. 2012a. Classificação das doenças, p.15-20. In: Sobestiansky J. \& Barcellos D. (Eds), Doenças dos Suínos. 2ª ed. Canône Editorial, Goiânia.

Staats J.J., Feder I., Okwumabua O. \& Chengappa M.M. 1997. Streptococcus suis: past and present. Vet. Res. Commun. 21(6):381-407.<https://dx.doi. org/10.1023/A:1005870317757><PMid:9266659>

Swenson S.L., Mead D.G. \& Kinker D.R. 2019. Rhabdoviruses, p.733-739. In Zimmermann J.J., Karriker L.A., Ramirez A., Schwartz K.J., Stevenson G.W. \& Zhang J. (Eds), Diseases of Swine. 11th ed. Wiley-Blackwell, Hoboken.

Vreman S., Caliskan N., Harders F., Boonstra J., Peperkamp K., Ho C.K.Y., Kuller W. \& Kortekaas J. 2020. Two novel porcine teschovirus strains as the causative agents of encephalomyelitis in the Netherlands. BMC Vet. Res. 16(1):51. <https://dx.doi.org/10.1186/s12917-020-2275-0>

Zlotowski P., Pavarini S.P., Bandinelli M.B., Langohr I.M. \& Driemeier D. 2013. Paralysis in pigs with spinal cord injury due to porcine circovirus type 2 (PCV-2) infection. Vet. Rec. 172(24):637. <https://dx.doi.org/10.1136/ vr.101409><PMid:23694922> 